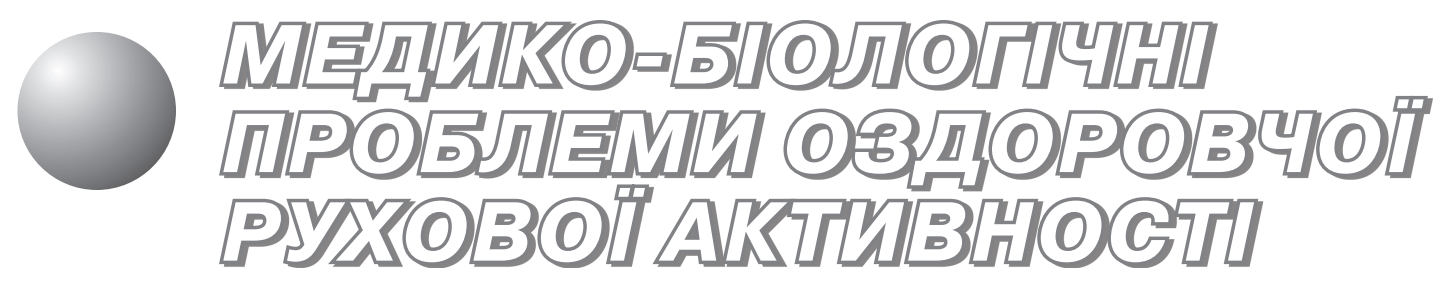

\title{
Адаптаційні резерви системи кровообігу залежно від рівня повсякденної рухової активності молоді
}

\author{
УДК: 612.76-053.81

\section{О. Є. Дорофєєва1, В. М. Коршак², К. С. Яримбаш} \\ ${ }^{1}$ Національний медичний університет ім. О. О. Богомольця, Київ, Україна \\ Дніпропетровський державний інститут фізичної культури і спорту, Дніпро, \\ Україна
}

Резюме. Мета. Визначити взаємозв'язок між рівнем повсякденної рухової активності, адаптаційними резервами системи кровообігу та частотою захворюваності студентської молоді для формування мотивації підвищення рівня фізичної підготовленості, запобігання розвитку патологічних процесів в організмі та покращення якості життя студентів. Методи: аналіз наукової та науково-методичної літератури, спостереження, бесіда, анкетування, тестування. Результати. Переважна кількість студентів займаються фізичною культурою менше ніж три години на тиждень або не займаються взагалі, що позначається на частоті їх захворюваності на ГРВІ протягом року, а також супроводжується хронічними змінами в роботі серцево-судинної, дихальної і травної систем. Функціональна рухливість системи кровообігу у фізично активної молоді значно досконаліша: дозоване фізичне навантаження у них забезпечується меншою активізацією хронотропного і більшою - інотропного резерву серця. Висновки. Своєчасна об'єктивізація функціональних змін в організмі молоді дозволяє вирішити проблеми профілактичних заходів, а діагностика функціональних резервів системи кровообігу може бути здійснена простими і доступними для масових обстежень функціональними пробами; проблема адаптаційних резервів системи кровообігу молоді залежно від повсякденної рухової активності потребує подальшого вивчення для мотивації до більш активного способу життя сучасної молоді.

Ключові слова: студентська молодь, рухова активність, мотивація, адаптаційні резерви системи кровообігу, захворювання, фізична культура.

Резюме. Цель. Определить взаимосвязь между уровнем повседневной двигательной активности, адаптационными резервами системы кровообращения и частотой заболеваемости студенческой молодежи для формирования мотивации повышения уровня физической подготовленности, предупреждения развития патологических процессов в организме и улучшения качества жизни студентов. Методы: анализ научной, научно-методической литературы, наблюдение, беседа, анкетирование, тестирование, эксперимент. Результаты. Подавляющее большинство студентов занимаются физической культурой менее трех часов в неделю или не занимаются совсем, что сказывается на частоте их заболеваемости ОРВИ в течение года, а также сопровождается хроническими изменениями в работе сердечнососудистой, дыхательной и пищеварительной систем. Функциональная подвижность системы кровообращения у физически активной молодежи более совершенна: дозированная физическая нагрузка у них обеспечивается меньшей активизацией хронотропного и большей инотропного резерва сердца. Выводы. Своевременная объективизация функциональных изменений в организме молодежи позволяет решить проблемы профилактических мероприятий, а диагностика функциональных резервов системы кровообращения может быть осуществлена простыми и доступными для массовых обследований функциональными пробами; проблема адаптационных резервов системы кровообращения молодежи в зависимости от повседневной двигательной активности требует дальнейшего изучения для мотивации к более активному образу жизни современной молодежи. 
Ключевые слова: студенческая молодежь, двигательная активность, мотивация, адаптационные резервы системы кровообращения, заболевания, физическая культура.

\begin{abstract}
Objective. To determine the relationship between the level of daily motor activity, the adaptation reserves of circulatory system and the incidence rate in student youth to form the motivation for increasing the level of physical fitness, preventing the development of pathological processes in the body and improving the quality of life of students. Methods: analysis of scientific and scientificmethodical literature, observations, discussion, questionnaire, testing. Results. The vast majority of students are either engaged in physical culture less than three times a week or are not engaged at all, which affects the frequency of acute respiratory viral infections among them during the year, and is accompanied by chronic changes in the work of the cardiovascular, respiratory and digestive systems. Functional mobility of the circulatory system in physically active youth is much more perfect: the dosed physical activity in them is provided by a less activation of the chronotropic and more - inotropic reserve of the heart. Conclusions. Timely objectivization of functional changes in the body of the youth allows to solve problems of preventive measures, whereas diagnostics of functional reserves of circulatory system can be carried out by simple and accessible for mass examinations functional tests. The problem of adaptation reserves of the circulatory system of young people, depending on the daily motor activity, requires further study to motivate a more active way of life of modern youth.
\end{abstract}

Keywords: student youth, motor activity, motivation, circulatory system adaptation reserves, disease, physical culture.

Постановка проблеми дослідження. Аналіз останніх досліджень і публікацій. Рухова активність $€$ найважливішим компонентом способу життя і поведінки молодої людини $[3,5,9,13,14]$. Вона визначається соціально-економічними умовами, рівнем культури суспільства, індивідуальними психофрізичними особливостями, кількістю вільного часу і характером його використання, доступністю спортивних споруд і місць відпочинку [6, 7, $11,12,17]$. При повсякденно обмеженій руховій активності (фрізичній інертності), яка характерна для більшості сучасної молоді, підвищується фрактор ризику розвитку хронічних захворювань, що згодом може призвести до летальних випадків [1, 2, 9, 16, 18, 21]. Найпоширенішою фрормою прояву обмеженої рухової активності у людей молодого віку $є$ фрункціональні захворювання, розвитку яких часто сприяє також хронічне отруєння організму нікотином, надмірне вживання кави, чаю, перенесені затяжні респіраторні захворювання, напружений спосіб життя. Дослідження провідних фрахівців свідчать про суттєвий взаємозв'язок між руховою активністю людини і частотою випадків серцево-судинних захворювань [4, 7-9].

У багатьох наукових дослідженнях визнано, що підвищення рівня рухової активності сприяє зниженню частоти серцево-судинних захворювань $[4,7,8,9]$. Однак експертиза одержаних результатів виявилась неоднозначною, і в багатьох роботах цю залежність не вдалося підтвердити [5, 15, 16, 18]. Найбільші труднощі виникають під час оцінки ізольованої дії низької рухової активності на частоту серцево-судинної патології, адже практично всі наукові роботи розглядають взаємозв'язок декількох фракторів ризику. Тому уявлення про роль рухової активності в профрілактиці серцево-судинних захворювань до сьогодні базується головним чином на непрямих даних. У той же час рухова активність - комплексне поняття поведінки людини, що характеризується відповідною складністю під час його вивчення. Однією з основних проблем у цьому напрямку $є$ кількісна оцінка рівня рухової активності. У більшості досліджень характеристики рівня рухової активності і методи його визначення не $\epsilon$ коректними, тому їх не можна порівнювати. Звідси, очевидно, і неоднозначність одержаних висновків. Більшість авторів до фрізично активних відносять осіб, які займаються фрізичною працею, тобто враховувалась тільки фрізична активність у робочий час $[1,6,7,12]$. При важкій фрізичній роботі зареєстровано вищу смертність від хронічної ішемічної хвороби серця, ніж у людей, зайнятих легкою фрізичною працею. Більш переконливі результати одержані авторами у процесі спостереження за здоровими особами, рухова активність яких враховувалась не тільки на роботі, але і під час відпочинку [4, $10,15,19,20]$.

Отже, проведений аналіз останніх досліджень і публікацій свідчить, що інтерес до проблеми дослідження i прогнозування здоров'я молоді залежно від рівня рухової активності достатньо високий і постійно зростає. Однак наразі практично відсутні дані щодо взаємозв'язку рівня повсякденної рухової активності, адаптаційних резервів системи кровообігу та частоти захворюваності у студентської молоді, що і зумовило актуальність проведення даного дослідження.

Зв'язок роботи 3 науковими програмами, планами, темами. Робота проводилася відповідно до Зведеного плану НДР на 2015-2017 рр. 
Міністерства охорони здоров'я України за темою «Якість життя та фрізична підготовленість молоді в залежності від повсякденної рухової активності» (номер держреєстрації 0115U000906).

Мета дослідження - визначити взаємозв'язок між рівнем повсякденної рухової активності, адаптаційними резервами системи кровообігу та частотою захворюваності студентської молоді для формування мотивації підвищення рівня рухової підготовленості, запобігання розвитку патологічних процесів в організмі та покращення якості життя студентів.

\section{Завдання дослідження:}

1. Визначити рівень повсякденної рухової активності та частоту захворюваності протягом року у студентської молоді.

2. Оцінити адаптаційні резерви системи кровообігу студентської молоді за реакцією організму на виконання дозованого фрізичного навантаження.

3. Провести порівняльний аналіз взаємозалежності рівня рухової активності студентської молоді від адаптаційних резервів системи кровообігу та частоти захворюваності.

Методи дослідження. Теоретичні: аналіз медичної, психологічної, соціально-методичної літератури для визначення теоретико-методологічних основ дослідження, сучасного стану проблеми фрізичної реабілітації та перспективних напрямків ії̈ вирішення; емпіричні: спостереження, бесіда, анкетування, тестування, експеримент для вивчення різноманітних аспектів досліджуваної проблеми, спрямованої на підвищення фізичної підготовленості студентської молоді та формування мотивації до регулярних занять 3 фрізичного виховання; статистичні: кількісна та якісна обробка експериментальних даних обстеження і результатів дослідження.

Організація дослідження. Було обстежено 598 студентів НМУ імені О. О. Богомольця під час практичних занять зі спортивної медицини, середній вік яких становив 23,0 $\pm 0,56$ років. Фізичну активність молоді вивчали і оцінювали за допомогою анкети, що надалі послужило основою для розподілу студентів на дві групи для проведення порівняльного аналізу: перша група - фрізично активні (ФА) студенти, які займаються фрізичної культурою три години на тиждень і більше, та друга група - фрізично інертні (ФІ) студенти, рівень фрізичної активності яких становить менше ніж три години на тиждень або взагалі відсутній.

Адаптаційні резерви системи кровообігу визначали за типом реакції організму на виконання дозованого фрізичного навантаження: за результатами проби Мартіне-Кушелевського, під час сходження на чотири поверхи стандартної будівлі та при виконанні активної ортостатичної проби. Тип реакції оцінювали за зміною показників ЧСС, АТсист, АТдіаст та АТп (пульсового артеріального тиску) до та після виконання навантажень.

Рівень захворюваності студентів визначали під час бесіди за інфеекційним індексом (кількість випадків перенесеної ГРВІ протягом року).

Результати дослідження та їх обговорення. Аналіз рівня рухової активності та частоти захворюваності студентської молоді показав, що три і більше годин на тиждень займаються фрізичною культурою в повсякденному житті лише $16 \%$ жінок і 38,7 \% чоловіків, які мають низький інфекційний індекс (частота захворюваності менша, ніж два рази на рік) і відсутність хронічних захворювань. Зворотну динаміку визначено в групі ФІ студентів. Так, кількість жінок, які займаються фрізичною культурою менше, ніж три години на тиждень, становила $40,7 \%$, у $43,3 \%$ рухова активність взагалі відсутня, однак частота захворюваності ГРВІ перевищує три-чотири рази на рік. Аналогічні показники встановлено в групі ФІ чоловіків. Так, 41,9 \% студентів зазначили, що займаються фрізичною культурою менше, ніж три години на тиждень, а 19,4 \% студентів констатують цілковиту відсутність занять фрізичною культурою. Слід також зазначити, що частота захворюваності серед чоловіків вища, ніж у жінок, і становила до 6 разів на рік (табл. 1).

Під час аналізу адаптаційних резервів системи кровообігу було визначено пряму залежність реакції організму на дозоване фрізичне навантаження та рівня повсякденної рухової активності.

У відповідь на дозоване фрізичне навантаження «20 присідань за 30 с» (проба МартінеКушелевського) майже у 50 \% обстежених було констатовано нормотонічний тип гемодинамічної реакції. При цьому суттєвої різниці розподілу обстеженої молоді залежно від рухової активності не виявлено. Гіпертонічний тип реагування було виявлено у третини обстежених. Частота цього типу також не була пов'язана з рівнем повсякденної рухової активності. Серед студентів жіночої статі випадків астенічного типу реагування було майже вдвічі більше в групі ФІ, ніж у групі ФА. Аналогічної закономірності серед чоловіків не спостерігалося. Дистонічний тип реагування було констатовано лише в поодиноких випадках обстеження. Більш детальний аналіз адаптаційних змін найпоширеніших типів гемодинамічного реагування дозволив встановити певні відмінності залежно від рівня рухової активності досліджуваних (табл. 2). При виконанні дозованого 
ТАБЛИЦЯ 1 - Розподіл студентів за рівнем рухової активності протягом тижня

\begin{tabular}{|l|c|c|c|c|c|c|c|}
\hline \multirow{2}{*}{ Група } & \multirow{2}{*}{$\mathbf{n}$} & \multicolumn{5}{|c|}{ Час заняття фізичною культурою, год } \\
\cline { 3 - 8 } & & \multicolumn{2}{|c|}{ три і більше } & \multicolumn{2}{|c|}{ менше трьох } & \multicolumn{2}{c|}{ не займалися } \\
\cline { 3 - 8 } & & абс. & $\%$ & абс. & $\%$ & абс. & $\%$ \\
\hline Жінки & 382 & 61 & 16,0 & 155 & 40,7 & 166 & 43,3 \\
Чоловіки & 216 & 83 & 38,7 & 91 & 41,9 & 42 & 19,4 \\
\hline
\end{tabular}

ТАБЛИЦЯ 2 - Взаємозалежність адаптаційних резервів системи кровообігу під час виконання проби МартінеКушелевського та рівня рухової активності молоді

\begin{tabular}{|c|c|c|c|c|c|c|c|c|c|c|c|}
\hline \multirow{3}{*}{ Група } & \multirow{3}{*}{$\mathbf{n}$} & \multicolumn{10}{|c|}{ Тип реакції на фізичне навантаження } \\
\hline & & \multicolumn{2}{|c|}{$\begin{array}{l}\text { нормото- } \\
\text { нічний }\end{array}$} & \multicolumn{2}{|c|}{$\begin{array}{l}\text { гіперто- } \\
\text { нічний }\end{array}$} & \multicolumn{2}{|c|}{$\begin{array}{l}\text { дисто- } \\
\text { нічний }\end{array}$} & \multicolumn{2}{|c|}{$\begin{array}{l}\text { гіпото- } \\
\text { нічний }\end{array}$} & \multicolumn{2}{|c|}{$\begin{array}{c}\text { астеніч- } \\
\text { ний }\end{array}$} \\
\hline & & абс. & $\%$ & абс. & $\%$ & абс. & $\%$ & абс. & $\%$ & абс. & $\%$ \\
\hline \multicolumn{12}{|c|}{ Чоловіки } \\
\hline Ф। & 105 & 21 & 20,0 & 34 & 32,3 & 7 & 6,6 & - & - & 43 & 41, \\
\hline ФA & 111 & 67 & 60,3 & 29 & 26,1 & - & - & - & - & 15 & 13,5 \\
\hline \multicolumn{12}{|c|}{ Жінки } \\
\hline Ф। & 231 & 17 & 7,3 & 72 & 31,1 & 11 & 4,7 & - & - & 131 & 56,9 \\
\hline$\Phi A$ & 151 & 63 & 41,7 & 44 & 29,1 & 3 & 1,9 & - & - & 41 & 27,3 \\
\hline
\end{tabular}

ТАБЛИЦЯ 3 - Розподіл обстежених за рівнями адаптації до фізичного навантаження за результатами сходження на чотири поверхи стандартної будівлі

\begin{tabular}{|c|c|c|c|c|c|c|c|c|c|c|c|}
\hline \multirow{3}{*}{ Група } & \multirow{3}{*}{$\mathbf{n}$} & \multicolumn{10}{|c|}{ Рівень } \\
\hline & & \multicolumn{2}{|c|}{ низький } & \multicolumn{2}{|c|}{$\begin{array}{c}\text { нижчий за } \\
\text { середній }\end{array}$} & \multicolumn{2}{|c|}{ середній } & \multicolumn{2}{|c|}{$\begin{array}{l}\text { вищий за } \\
\text { середній }\end{array}$} & \multicolumn{2}{|c|}{ високий } \\
\hline & & абс. & $\%$ & абс. & $\%$ & абс. & $\%$ & абс. & $\%$ & абс. & $\%$ \\
\hline \multicolumn{12}{|c|}{ Чоловіки } \\
\hline Ф। & 105 & 49 & 46,6 & 29 & 27,6 & 13 & 12,3 & 12 & 11,4 & 2 & 2,1 \\
\hline ФА & 111 & 36 & 32,4 & 25 & 22,5 & 21 & 18,9 & 22 & 19,8 & 7 & 6,4 \\
\hline \multicolumn{12}{|c|}{ Жінки } \\
\hline$\Phi \mid$ & 231 & 128 & 55,4 & 44 & 19,0 & 23 & 9,9 & 19 & 8,2 & 17 & 7,5 \\
\hline$\Phi \mathrm{A}$ & 151 & 26 & 17,2 & 24 & 15,8 & 27 & 17,8 & 16 & 10,6 & 58 & 38,6 \\
\hline
\end{tabular}

ТАБЛИЦЯ 4 - Реакція симпатичного відділу ВНС на ортостатичну пробу за адаптаційними змінами хронотропного резерву серця

\begin{tabular}{|l|c|c|c|c|c|c|c|}
\hline \multirow{2}{*}{ Група } & \multirow{8}{*}{$\mathbf{n}$} & \multicolumn{8}{|c|}{ Рівень } \\
\cline { 4 - 8 } & & \multicolumn{2}{|c|}{ нормальний } & \multicolumn{2}{|c|}{ підвищений } & \multicolumn{2}{|c|}{ знижений } \\
\cline { 3 - 8 } & & абс. & $\%$ & абс. & $\%$ & абс. & $\%$ \\
\hline \multicolumn{8}{|c|}{ ФІловіки } \\
ФА & 105 & 12 & 11,4 & 79 & 75,2 & 14 & 13,4 \\
ФІ & 111 & 84 & 75,7 & 27 & 24,3 & - & - \\
ФА & 231 & 47 & 20,3 & 167 & 72,2 & 17 & 7,35 \\
& 151 & 115 & 76,1 & 24 & 15,8 & 12 & 7,9 \\
\hline
\end{tabular}

фрізичного навантаження з нормотонічним типом реагування гемодинамічні показники в групі ФА чоловіків суттєво відрізнялись від групи ФІ, що відобразилося в змінах ЧСС (зниженні) та АТ (зростання АТсист та зниження АТдіаст).

Гемодинамічні показники в групі ФА жінок порівняно з ФІ характеризувались меншим приростом ЧСС і більшим зростанням АТсист. Різниця в змінах АТдіаст у цих жінок була несуттєвою. При цьому вихідні рівні параметрів, що контролювались як у чоловіків, так і жінок, не відрізнялись. У обстежених $з$ гіпертонічним типом реагування гемодинамічні показники в групі ФА чоловіків, на відміну від групи ФІ, також відрізнялись значно меншим приростом ЧСС та суттєво більшим приростом АТп (табл. 2).

Розподіл студентів за рівнем адаптаційних резервів системи кровообігу (пульсова вартість 1 Вт фрізичного навантаження) при сходженні на чотири поверхи стандартної будівлі представлено в табл. 3. Низький рівень адаптації значно частіше виявляється в групах ФІ студентів чоловічої і жіночої статі (46,6 і 55,4 \% відповідно). Середній, вищий за середній і високий рівень адаптаційних резервів системи кровообігу переважав у групах ФА молоді. Слід зазначити, що жінки в групі ФА мали достовірно вищий рівень адаптації до фрізичного навантаження порівняно з чоловіками тієї ж групи (38,6 та 6,4 \% відповідно). Потужність фрізичного навантаження, яку долали обстежені при сходженні на чотири поверхи, в групах порівняння суттєво не відрізнялась $(133,3 \pm 3,8$ і 139,2 $\pm 3,8$ Вт у чоловіків i 109,4 \pm 2,7 і 111,2 \pm 3,2 Вт у жінок). Але при цьому пульсова вартість 1 Вт навантаження в групах ФА чоловіків і жінок була значно меншою (тобто адаптаційні резерви були більшими), ніж у групах ФІ студентів (0,99 $\pm 0,03$ Вт проти 0,87 \pm 0,03 Вт і 1,31 \pm 0,04 Вт проти 1,18 \pm 0,04 Вт відповідно).

Ортостатичну пробу всі обстежені перенесли суб'єктивно добре. У більшості студентів обох статей, які належали до групи ФІ, виявили підвищений рівень реагування симпатичного відділу вегетативної нервової системи (ВНС). Нормальний рівень реакції на ортостатичну пробу значно частіше реєстрували в групах ФА чоловіків і жінок. Знижений рівень реакції зафріксовано лише у 14 чоловіків і 17 жінок, у яких рівень рухової активності був найнижчим (табл. 4).

Одночасно з активізацією хронотропного резерву серця спостерігали певні адаптаційні інотропні зміни (табл. 5). При нормальній реакції симпатичного відділу ВНС зміни АТсист у групах ФА чоловіків і жінок були суттєво меншими, ніж у групах ФІ. У групах ФА жінок і чоловіків 3 
ТАБЛИЦЯ 5 - Реакція симпатичного відділу ВНС на ортостатичну пробу за адаптаційними змінами інотропного резерву серця

\begin{tabular}{|l|c|c|c|c|c|}
\hline \multirow{2}{*}{ Група } & \multirow{2}{*}{$\mathbf{n}$} & \multicolumn{5}{|c|}{ Рівень } \\
\cline { 4 - 7 } & & \multicolumn{2}{|c|}{ нормальний } & \multicolumn{2}{|c|}{ підвищений } \\
\cline { 3 - 7 } & & абс. & $\%$ & абс. & $\%$ \\
\hline \multicolumn{6}{|c|}{ Чоловіки } \\
ФІ & 105 & 31 & 29,5 & 74 & 70,5 \\
ФА & 111 & 69 & 62,1 & 42 & 37,8 \\
& \multicolumn{7}{|c|}{ Жінки } \\
ФІ & 231 & 92 & 39,8 & 139 & 60,2 \\
ФА & 151 & 97 & 64,2 & 54 & 35,7 \\
\hline
\end{tabular}

підвищеним типом реагування симпатичного відділу ВНС на активну ортостатичну пробу зміни АТдіаст були суттєво більшими, ніж у групах ФІ студентів. Реакція АТ на зміну положення тіла від рівня рухової активності обстежених не залежала.

\section{Висновки.}

1. Аналіз рівня рухової активності та частоти захворюваності студентської молоді показав, що

\section{Література}

1. Анікєєв Д. М. Проблеми формування здорового способу життя студентської молоді / Д. М. Анікєєв // Педагогіка, психологія та мед.-біол. пробл. фіз. виховання і спорту. - 2009. - № 2. - С. 6-9.

2. Базильчук В. Б. Динаміка рівня фізичної підготовленості студентів технічних ВН3 впродовж навчання // Українські технології. - 2003. - Вип 7, T. 2. - C. $259-262$

3. Башавець Н. А. Стан захворюваності сучасної студентської молод та шляхи його поліпшення / Н. А. Башавець // Педагогіка, психологія та мед.біол. пробл. фіз. виховання і спорту. - 2011. - № 7. - С. 6-10.

4. Бушуєв Ю. В. Рівень фізичного здоров'я студентів як клініко-фізіологічна основа фізичного виховання у вузі : дис. ... канд. мед. наук : спец. 14.01.24 «Лікувальна фізкультура та спорт. Медицина» / Ю. В. Бушуєв. Дніпропетровськ, 2007. - 21 c.

5. Грибан Г. П. Аналіз рухової активності студентів спеціального навчального відділення / Г. П. Грибан // Педагогіка, психологія та мед.-біол. пробл. фіз. виховання і спорту. - 2012. - № 2. - С. 25-28.

6. Грибан Г. П. Аналіз стану здоров'я абітурієнтів та студентів, які проживають у негативних умовах навколишнього середовища / Г. П. Грибан // Теорія і практика фіз. виховання. - 2004. - № 2. - С. 145-149.

7. Дорофреева E. Е. Интеграция медицины и физической культуры для улучшения здоровья студенческой молодежи Украины / Е. Е. Дорофеева, И. В. Карпенко // Теорія і практика фіз. виховання. - 2012. - Т. 1. C. $135-142$.

8. Король С. А. Оцінка стану соматичного здоров'я та фізичної підготовленості студентів I курсу технічних спеціальностей / С. А. Король // Педагогіка, психологія та мед.-біол. пробл. фіз. виховання і спорту. - 2014. № 11. - С. 23-29.

9. Кутек Т. Б. Аналіз стану здоров'я студентів вищих навчальних закладів / Т. Б. Кутек, Г. П. Грибан // Спорт. вісн. Придніпров'я. - 2004. - № 7 . C. $130-132$.

10. Малахова Ж. В. Здоров'ясормуючі технології в процесі фізичного виховання студентів спеціальних медичних груп [Електронний ресурс] Ж. В. Малахова. - Режим доступу : irbis-nbuv. Gov. Ua/cgi-bin/../cgiirbis_64. Exe. -2013 переважна кількість студентів займаються фрізичною культурою менше, ніж три години на тиждень або не займаються взагалі, що позначається на частоті їх захворюваності на ГРВІ протягом року.

2. Функціональна рухливість системи кровообігу у ФА молоді значно досконаліша: дозоване фрізичне навантаження у них забезпечується меншою активізацією хронотропного і більшою інотропного резерву серця.

3. Своєчасна об'єктивізація функціональних змін в організмі молоді дозволяє вирішити проблеми профрілактичних заходів, а діагностика фрункціональних резервів системи кровообігу може бути здійснена простими і доступними для масових обстежень функціональними пробами.

4. Проблема адаптаційних резервів системи кровообігу молоді залежно від повсякденної рухової активності потребує подальшого вивчення для мотивації до більш активного способу життя сучасної молоді.

Перспективи використання результатів дослідження. Розробка та впровадження в процес фрізичного виховання у ВНЗ практичних рекомендацій для підвищення мотивації студентів заняттями з фрізичного виховання.

\section{References}

1. Anikyeyev, D.M. (2009). Problemy formuvannya zdorovoho sposobu zhyttya studentskoyi molodi [Problems of formation of a healthy way of life of student youth]. Pedahohika, psykholohiya ta medyko-biolohichni problemy fizychnoho vykhovannya i sportu - Pedagogy, psychology and medical and biological problems of physical education and sports, 2, 6-9 [in Ukrainian].

2. Bazilchuk V.B. (2003). Dynamika rivnya fizychnoyi pidgotovlenosti studentiv tekhnichnykh VNZ vprodovzh navchannya [Dynamics of level of physical preparedness of students of technical universities during study]. Ukrayins'ki tekhnolohiyi Ukrainian technologies, 7, 2, 259-262.

3. Bashavets, N.A. (2011). Stan zakhvoryuvanosti suchasnoyi studentskoyi molodi ta shlyakhy yoho polipshennya [The state of morbidity of modern student youth and ways of its improvement]. Pedahohika, psykholohiya ta medykobiolohichni problemy fizychnoho vykhovannya i sportu - Pedagogy, psychology and medical and biological problems of physical education and sports, 7, 6-10 [in Ukrainian].

4. Bushuyev, Yu.V. (2007). Riven fizychnoho zdorovya studentiv yak klinikofiziolohichna osnova fizychnoho vykhovannya u VUZi [The level of physical health of students as a clinical and physiological basis of physical education in high school]. Candidate's thesis. Dnipropetrovsk [in Ukrainian].

5. Hryban, H.P. (2012). Analiz rukhovoyi aktyvnosti studentiv spetsialnoho navchalnoho viddilennya [Analysis of motor activity of students of a special educational department]. Pedahohika, psykholohiya ta medykobiolohichni problemy fizychnoho vykhovannya i sportu - Pedagogy, psychology and medical and biological problems of physical education and sports, 2, 25-28 [in Ukrainian].

6. Hryban, H.P. (2004). Analiz stanu zdorov'ya abituriyentiv ta studentiv, yaki prozhyvayut $v$ nehatyvnykh umovakh navkolyshnoho seredovyshcha [An analysis of the health status of university entrants and students living in negative environmental conditions]. Teoriya i praktyka fizychnoho vykhovannya - The theory and practice of physical education, 2, 145-149 [in Ukrainian].

7. Dorofeeva, E.E., \& Karpenko, I.V. (2012). Integratsiya meditsinyi fizicheskoy kulturyi dlya uluchsheniya zdorovya studencheskoy molodezhi Ukrainyi [Integration of Medicine and Physical Education to improve the health of students in 
11. Носко М. О. Теоретико-методичні аспекти зміцнення фізичного здоров'я учнівської та студентської молоді / М. О. Носко, С. С. Єрмаков, С. В. Гаркуша // Вісн. Чернігів. нац. пед. ун-ту ім. Т. Г. Шевченка. - 2010. С. 243-247. - (Педагогічні науки. Фізичне виховання і спорт).

12. Редько Т. М. Проблема збереження здоров'я студентів на сучасному етапі розвитку системи вищої освіти / Т. М. Редько // Вісн. Чернігів. нац. пед.ун-ту ім. Т. Г. Шевченка. - 2015. - С. 45-48. - (Педагогічні науки).

13. Томенко О. А. Рівень соматичного здоров'я і рухової активності студентів вищих навчальних закладів / О. А. Томенко, С. А. Лазоренко // Слобожан. наук.-спорт. вісн. - 2010. - № 2. - С. 17-20.

14. Цьось А. В. Рухова активність у мотиваційно-ціннісних орієнтаціях студентів / А. В. Цьось, А. Б. Шевчук, О. З. Касарда // Фіз. виховання, спорт культура здоров'я у сучас. суспільстві. - 2016. - № 4 (28). - С. 83-87.

15. Gyurcsik N. C. An ecologically based examination of barriers to physical activity in students from grade seven through first-year university / N. C. Gyurcsik // J. of Adolescent Health. - 2006. - Vol. 38, N 6. - C. 704-711.

16. Lobelo F. Physical activity habits of doctors and medical students influence their counselling practices / F. Lobelo, J. Duperly, E. Frank // Brit. J. of Sports Medicine. - 2009. - Vol. 43, N 2. - C. 89-92.

17. Fox C. K. Physical activity and sports team participation: Associations with academic outcomes in middle school and high school students / C. K. Fox /I J. of School Health. - 2010. - Vol. 80, N 1. - C. 31-37.

18. Gao Z. Effects of curricular activity on students' situational motivation and physical activity levels / Z. Gao // Research quarterly for exercise and sport. 2011. - Vol. 82, N 3. - C. 536-544.

19. Taylor I. M. Motivational predictors of physical education students' effort, exercise intentions, and leisure-time physical activity: A multilevel linear growth analysis / I. M. Taylor // J. of Sport and Exercise Psychology. - 2010. - Vol. 32 N 1. - C. 99-120.

20. Lonsdale C. Self-determined motivation and students' physical activity during structured physical education lessons and free choice periods / C. Lonsdale // Preventive medicine. - 2009. - Vol. 48, N 1. - C. 69-73.

21. Standage M. Predicting students' physical activity and health-related well-being: A prospective cross-domain investigation of motivation across school physical education and exercise settings / M. Standage //J. of Sport and Exercise Psychology. - 2012. - Vol. 34, N 1. - C. 37-60.

\section{Спортивна медицина і фізична реабілітація, № 1, 2017}

Ukraine]. Teoriya i praktyka fizychnoho vykhovannya - The theory and practice of physical education, 1, 135-142 [in Russian].

8. Korol, S.A. (2014). Otsinka stanu somatychnoho zdorovya ta fizychnoyi pidhotovlenosti studentiv I kursu tekhnichnykh spetsialnostey [Assessment of the state of physical health and physical fitness of students of the 1st year of technical specialties]. Pedahohika, psykholohiya ta medyko-biolohichni problemy fizychnoho vykhovannya i sportu - Pedagogy, psychology and medical and biological problems of physical education and sports, 11, 23-29 [in Ukrainian].

9. Kutek, T.B., \& Hryban, H.P. (2004). Analiz stanu zdorov'ya studentiv vyshchykh navchal'nykh zakladiv [Analysis of the health status of students of higher educational institutions]. Sportyvnyy visnyk Prydniprov'ya - Sport Newspaper Prydniprovia, 7, 130-132 [in Ukrainian].

10. Malakhova, Zh.V. (2013). Zdorovyaformuyuchi tekhnolohiyi v protsesi fizychnoho vykhovannya studentiv spetsialnykh medychnykh hrup [Healthforming technologies in the process of physical education of students of special medical groups]. (n.d.). irbis-nbuv. Gov. Ua. Retrieved from irbis-nbuv. Gov. Ua/cgibin/.../cgiirbis_64. Exe [in Ukrainian].

11. Nosko, M.O., Yermakov, S.S., \& Harkusha, S.V. (2010). Teoretykometodychni aspekty zmitsnennya fizychnoho zdorovya uchnivskoyi ta studentskoyi molodi [Theoretical and methodical aspects of strengthening physical health of students and students]. Visnyk Chernihivskoho natsionalnoho pedahohichnoho universytetu imeni T.H. Shevchenka. Seriya "Pedahohichni nauky. Fizychne vykhovannya $i$ sport» - Bulletin of the Chernigiv National Pedagogical University named after T.G. Shevchenko. Ser. «Pedagogical sciences. Physical education and sports», $243-247$ [in Ukrainian].

12. Redko, T.M. (2015). Problema zberezhennya zdorovya studentiv na suchasnomu etapi rozvytku systemy vyshchoyi osvity [The problem of preserving the health of students at the present stage of the development of the higher education system]. Visnyk Chernihivskoho natsionalnoho pedahohichnoho universytetu imeni T.H. Shevchenka. Seriya «Pedahohichni nauky»Bulletin of the Chernigiv National Pedagogical University named after T.G. Shevchenko. Ser. «Pedagogical sciences», 45-48 [in Ukrainian].

13. Tomenko, O.A., \& Lazorenko, S.A. (2010). Riven somatychnoho zdorovya i rukhovoyi aktyvnosti studentiv vyshchykh navchalnykh zakladiv [Level of physical health and motor activity of students of higher educational institutions]. Slobozhanskyy naukovo-sportyvnyy visnyk - Slobozhansky Scientific and Sport Herald, 2, 17-20 [in Ukrainian].

14. Tsos, A.V., Shevchuk, A.B., \& Kasarda, O.Z. (2016). Rukhova aktyvnist u motyvatsiyno-tsinnisnykh oriyentatsiyakh studentiv [Motor activity in students' motivational and value orientations]. Fizychne vykhovannya, sport $i$ kultura zdorovya u suchasnomu suspilstvi - Physical education, sports and health culture in modern society, 4 (28), $83-87$ [in Ukrainian].

15. Gyurcsik, N.C. (2006). An ecologically based examination of barriers to physical activity in students from grade seven through first-year university. Journal of Adolescent Health, 38, 6, 704-711.

16. Lobelo, F., Duperly, J., \& Frank, E. (2009). Physical activity habits of doctors and medical students influence their counselling practices. British Journal of Sports Medicine, 43, 2, 89-92.

17. Fox, C.K. (2010). Physical activity and sports team participation: Associations with academic outcomes in middle school and high school students. Journal of School Health, 80, 1, 31-37.

18. Gao, Z. (2011). Effects of curricular activity on students' situational motivation and physical activity levels. Research quarterly for exercise and sport, 82, 3, 536-544.

19. Taylor, I.M. (2010). Motivational predictors of physical education students' effort, exercise intentions, and leisure-time physical activity: A multilevel linear growth analysis. Journal of Sport and Exercise Psychology, 32, 1, 99-120.

20. Lonsdale, C. (2009). Self-determined motivation and students' physical activity during structured physical education lessons and free choice periods. Preventive medicine, 48, 1, 69-73.

21. Standage, M. (2012). Predicting students' physical activity and health-related well-being: A prospective cross-domain investigation of motivation across school physical education and exercise settings. Journal of Sport and Exercise Psychology, 34, 1, 37-60. 